\title{
Examining life quality in Hajdúszoboszló Tourist Area, with a special focus on health conditions
}

\author{
Anett Sőrés ${ }^{1}$, Károly Petö ${ }^{2}$, Margit Csipkés ${ }^{3}$
}

\begin{tabular}{ll}
\hline I N F O & A B S T R A C T \\
$\begin{array}{l}\text { Received 22 Jan. 2012 } \\
\text { Accepted 23 March. 2012 }\end{array}$ & $\begin{array}{l}\text { The present study discusses the partial results of a more comprehensive research and its } \\
\text { Available on-line 15 Jun. 2012 } \\
\text { Responsible Editor: K. Rajkai } \\
\text { explore the interrelationship of health tourism and the quality of life. Our study merely } \\
\text { focuses on the analysis and the introduction of factors that determine health condition. }\end{array}$ \\
$\begin{array}{l}\text { Keywords: } \\
\text { health condition, willingness to } \\
\text { do sports, quality of life. }\end{array}$ & $\begin{array}{l}\text { Good health in itself is not enough, qualitative life requires physical-psychological well- } \\
\text { being as well. Years lost from lives due to poor health and early death result not only in } \\
\text { human but economic losses as well; so it is highly recommended to dedicate time, money } \\
\text { and energy to its investigation. }\end{array}$
\end{tabular}

\section{Introduction}

Nowadays people are increasingly conscious about their physical conditions and have realized that both in their professional and private lives outer appearance and sufficient health are instrumental for their welfare. Besides fitness, health conservation, health diet, personal care and beauty treatment often come in the limelight and fitness has developed into a way of life. These days not only women, but also men do sports regularly and they place a high priority on the preservation of their health. Various companies and firms have also realized that the preservation of the physical and mental health of their staff is indispensable in fierce market competition, so they also need to support these efforts. On the other hand, the health of our population is in a much worse condition than indicated by the actual economic situation of the country.

The mortality rate of younger age groups has been growing for years, the number of premature deaths is extremely high, and the mortality of middle-aged men has become outstanding on a world scale. All these suggest that this significant element of the quality of life should remain at the forefront of research.

\section{Material and method}

Our research process used methods of both primary and secondary data collection. Secondary research processed national and international professional literature and data provided by the Central Statistical Office.

Primary research included filling in 805 questionnaires in Hajdúszoboszló. The sample included only local residents, as our main objective was to explore the factors influencing the quality of their lives.

The questionnaires were evaluated by the Statistical Package for Social Science (SPSS) program.

\footnotetext{
1 Anett Sörés

University of Debrecen, 4032 Debrecen, Böszörményi út 138., Hungary e-mail: soresanett@agr.unideb.hu

2 Károly Pető

University of Debrecen, e-mail: peto@agr.unideb.hu

3 Margit Csipkés

University of Debrecen, e-mail: csipkesm@agr.unideb.hu
} 


\section{Result and discussion}

\subsection{About the quality of life}

On one hand, tourism boosting regional competitiveness becomes a driving force to improve the quality of life in the given locality by meeting visitors' demands (the establishment of service industries) and on the other hand by improving the living conditions of local population (creation of a liveable settlement) (Dobos and Jeffres, 1993; Jurowski and Brown, 2001). It is well-known that Hungarian population addresses considerable challenges in terms of physical and mental health (Kopp and Pikó, 2006) and the active use of health tourism supply may favourably influence certain determinant factors of their life quality. For this reason, we have selected Hajdúszoboszló for our research area. Already from the 70s, research activities were carried out in the Workshop of Sociology of Values, Institute of Sociology, Hungarian Academy of Sciences (Hankiss et al., 1980, 1981, 1982; Hankiss and Manchin, 1976, 1977). This has not changed in the course of time, as sociologists are keen to identify issues related to the quality of life and subjective life quality (Lengyel and Hegedüs, 2002; Lengyel and Janky, 2002; Utasi, 2000, 2002; Skrabszki and Kopp, 1999).

Most research investigates the subjective quality of life in its narrowest sense, in which "besides the subjective estimation of respondents' individual or social situation, they also qualify this situation, whether on the level of conscious decisions or on emotional grounds" (Hegedüs, 2001, 2002). However, even within this narrowest sense, definitions feature high diversity (definitions of the subjective quality of life are summarized by Berger and Schmidtt 2000; Diener et al., 2000; Diener et al., 1997).

Inglehart and Klingemann claim that a significant element for the judgement of the quality of life is whether a specific country looks back on communist past or on democratic establishment with old traditions. In former socialist countries the judgement of individual welfare is not only more pessimistic than in traditional democracies, but it is often bleaker than in countries where communism still prevails. The reason by Veenhoven (1997) is that a more equal distribution of happiness is rather characteristic of countries, where the differences in incomes are lower and where social stability is high. Lengyel and Hegedüs (2002) state that the economic crisis resulting in political transformations have influenced subjective well-being in post-socialist countries negatively in itself. This is further deteriorated by the lack of immediate or at least faster fulfilment of change-related expectations and concomitant, growing uncertainty of existence (Inglehart and Klingemann 2000).

The basis of present day research on the quality of life dates back to Aristotle, as we can find the tendency of so-called positive psychology in the background of the psychological examination of the quality of life, which is built on Aristotle's' definition of happiness. It says that the quality of life equals with happiness. Accordingly, Aristotle lists three levels of happiness. The first one is pleasure, the level of hedonistic enjoyment of life. Happiness and joy play a significant part in the development and maintenance of favourable quality of life and a positive view of life; however, this state of mind should not be fully identified with happiness and well-being. As to this psychological approach the second level for the quality of life is "involvement", the state of commitment, when the individual finds satisfaction in performing a task or fulfilling an objective. This holistic experience that people feel when they act with total involvement during the performance of various joyful tasks is called "flow" (Csíkszentmihályi, 1998).

\subsubsection{Types of quality of life, health condition}

As the quality of life includes both objective and subjective elements, the former is measured by indicators of objective welfare and the latter by questions addressing satisfaction (Fekete, 2006). To this end, research on the quality of life mostly uses two concepts of the quality of life: objective and subjective. According to Diener's definition "subjective quality of life is how people evaluate their own lives including happiness, satisfaction with life, pleasant feelings and the relative lack of unpleasant states and feelings (Diener et al., 1997). Within the (continuously expanding and expandable) group of subjective social indicators we can distinguish three large sub-groups: 
- The first sub-group includes all the indicators based on personal opinion which may measure social welfare indirectly, but they do not explicitly focus on it. They include e.g. subjective social status, preferred ways of spending taxes etc.

- The second, narrower sub-group lists those indicators which specifically include "welfare perceptions" of individuals, i.e. they are based on the direct - conscious or emotional judgement of respondents about personal or social welfare. The indicators listed here are the following: the estimated economic situation and development of the country, the evaluation of one's personal income, expectations related to the economic situation of the country and one's personal financial situation or the estimated rate of realizing justness, etc. Questions addressing feelings in relation to welfare should also be included here, e.g. rate of fears of various crimes.

- Finally, subjective indicators include a third, somewhat special sub-group in which respondents, besides subjectively judging their personal or social situations, also qualify this situation on the level of conscious decision bringing or on emotional grounds. This group typically includes questions about respondents' feelings of satisfaction and happiness.

In the research of the quality of life and living conditions, objective indicators primarily refer to income conditions, labour-market status, endowment with consumer goods and other similar material indicators, or more generally, e.g. in international comparative terms, mainly to indices converted principally from national economic indicators (Utasi, 2000).

Research findings on subjective quality of life confirm that subjective quality of life depends not only on individual physical or mental health, demographic or economic situation, but it has a further "social" determinant: it depends on the quality of personal relationships as well (e.g. Leon et al., 2001; Fisher, 2000-2002; Inglehart and Klingemann 2000; Albrecht and Devlieger 1999; Bosworth and Schaie 1997; Cameron et al. 1973).

Since the 70s, morbidity research on deteriorating health condition in Hungary has focused on the evaluation of risk factors influencing health and on lifestyle surveys (Klinger 1987; Losonczi 1986, 1989), and thirdly, on the introduction of mental health (Kopp et al., 1999, 2000).

The territorial distribution of health, state of health, illness and mortality should be best described by the concept of inequality. Not only in Hungary, but also in developed countries significant inequalities are detected in terms of health, illness and mortality. Since the early 80s "health inequalities" in state of health and in health care systems have become increasingly significant social problems and research topics. Great Britain, the front runner of this research published the so-called Black report, listing the facts and issues which have sparked continually intensifying research activities (Black et al., 1985).

\subsection{The studied resort}

Hajdúszoboszló town is situated from about $21 \mathrm{~km}$ from Debrecen in the middle of Hajdú-Bihar County in the Eastern part of Hungary. The town features outstanding transport-geographic conditions: motorway M35 completed at the end of 2006 joins main road 4. at the administrative boundary of Ebes and Debrecen, significantly improving the accessibility of Hajdúszoboszló. Moreover, the town is situated halfway between Derecske and Balmazújváros, two other towns of regional significance. It is directly connected to all the three settlements in the small region by highways, and its catchment area partially covers the small area of Püspökladány through Kaba and Nádudvar.

Key issues for inhabitants in the town and for local hospitality employees are the following: as a result of development and growth

- how will Hajdúszoboszló be able to preserve and renew its natural, social, cultural and economic resources;

- what pace of development is acceptable for the town without disadvantageous changes; 
- what are the potential avenues of further development, what investments, infrastructural developments are required;

- how can visitors and local inhabitants respect each other's customs and traditions.

For more than 70 years Hajdúszoboszló has been called "the Mecca of rheumatic patients" and the "paradise of beachgoers" by Hungarian and foreign guests who seek remedy for their diseases. Since 1925 - following the outburst of the thermal spring of $73^{\circ} \mathrm{C}$, it has seen tremendous development. The town has become not only one of the touristic destinations of "Hajdú Golden Triangle" (DebrecenHajdúszoboszló-Hortobágy) but after Hévíz, Lake Balaton and Budapest, the fourth most popular health and holiday resort. This is a fact which evidently influences the health condition of local residents.

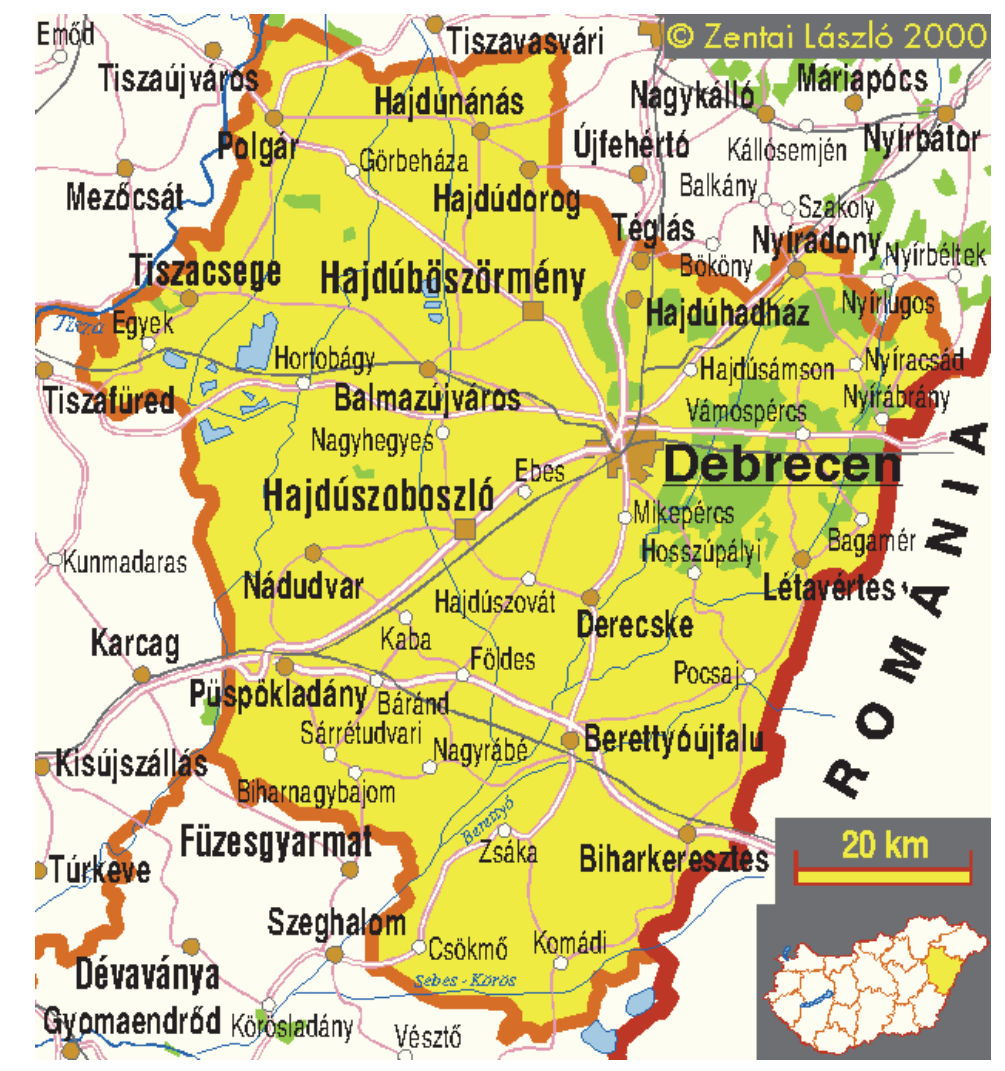

Figure 1. Figure Caption

Source: www.hajduszoboszlo.hu

The chemical composition of medicinal water in Hajdúszoboszló lends itself to healing several diseases. Over the past 70 years patients suffering from complaints of the locomoter system found treatments here. The medicinal water of Hajdúszoboszló is highly suitable for healing chronic disorders of the locomotor system, rheumatic pain, surgical, neural, medical and dermatological conditions, and the follow-up treatment of stroke, orthopaedic operations, paralysis, chronic neuralgia, chancre on lower extremities, gynaecological inflammations, infertility, muscle and bone injuries. In addition to hydrotherapy, the healing power of the water is further enhanced by mud-packs, medical massage, underwater jet massage treatment, therapeutic gymnastics and weight bath treatments.

The water of medicinal springs is also excellent not only for water cures, but for drinking cures as well. It heals gastric ulcer, catarrh, liver and gall-bladder inflammations.

\section{Evalution of findings}

The present article primarily focuses on health and its determinants. It is widely known these days that Hungarian people's life expectancy is much shorter and the quality of their health is much lower 
than it is expected regarding the level of economic-social conditions. Rapid social transformations and insecurity about life prospects have incited social tension and mounted burdens on certain population layers exceeding their capacity, which left people sick with various diseases and deviant lifestyle problems. Responsibility also rests with individual attitude and lifestyle. Data by the Central Statistical Office reveal that life expectancy for average Hungarian women is 77 years, whereas it is almost ten years' shorter for men who typically die at the age of 68. According to Hungarostudy 2008 data every third Hungarian man and every sixth woman do not live to see their 65 . birthdays. Unfortunately women die 6 years earlier and men 8 years earlier than EU average. The few who live to be 80 are usually unable to live self-reliantly and even personal hygiene is problematic for them.

The vast majority of problems are caused by the lack of physical activity or its gradual decrease. Almost $70 \%$ of Hungarians fail to do sports as they prefer other free time activities.

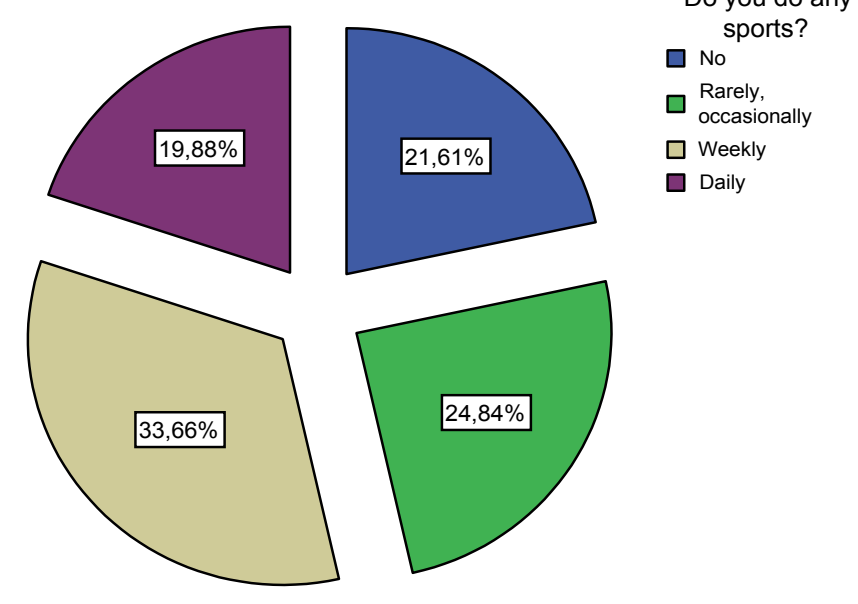

Figure 2. Sporting activity in Hajdúszoboszló

Source: Authors' own research

Figure 2. demonstrates sporting activity in Hajdúszoboszló. 20\% of respondents do sports on a daily basis, whereas $34 \%$ weekly. This is excellent as compared to Hungarian average values (as mentioned above, $70 \%$ are not engaged in sports). Survey findings also disclose (Table 1.) that the lowest amount of physical activity is performed by the age group above 61 years $(19 \%$ exercise on a daily basis), which boosts the development and the aggravation of old age diseases. Nevertheless, the age group under 20 cannot take pride in much better results, as merely $30 \%$ of young people pursue sport daily. The daily amount of exercises should be 20 minutes to maintain the health of body functions.

Table 1. Sporting activity by age groups

\begin{tabular}{|c|c|c|c|c|c|}
\hline & & \multicolumn{4}{|c|}{ How old are you? } \\
\hline & & Under 20 years & $21-40$ years & 41-60 years & Above 61 years \\
\hline \multirow[t]{4}{*}{$\begin{array}{l}\text { Do you do any } \\
\text { sports? }\end{array}$} & & 8,2 & 19,5 & 21,0 & 35,0 \\
\hline & $\begin{array}{l}\text { Rarely, } \\
\text { occasionally }\end{array}$ & 172 & 287 & 26.2 & 235 \\
\hline & Weekly & 44,0 & 35,9 & 34,2 & 22,4 \\
\hline & Daily & 30,6 & 15,9 & 18,6 & 19,1 \\
\hline Total & & 100 & 100 & 100 & 100 \\
\hline
\end{tabular}

Source: Authors' own research

Table 2. represents willingness to do exercises by sex. Unfortunately women move less, as merely $50 \%$ of female respondents pursue physical activities daily or weekly. This is not surprising, as much 
higher burdens are imposed on women than on men. They need to juggle household chores and child care, therefore sport often falls in the background.

Table 2. Sports by sex

\begin{tabular}{|ll|rr|}
\hline \multicolumn{2}{|c|}{$\%$} \\
\cline { 3 - 4 } & & \multicolumn{2}{|c|}{ What is your sex? } \\
\hline Do you do any & & Woman \\
sports? & No & 20 & 23,42 \\
& Rarely, occasionally & 24,94 & 24,74 \\
& Weekly & 32,24 & 35,26 \\
& Daily & 22,82 & 16,58 \\
Total & & 100 & 100 \\
\hline
\end{tabular}

Source: Authors' own research

Unfortunately, in international comparative terms the rate of physically active Hungarian adolescents is very low, we are at the end of the list in each studied age group.

Figure 3-4. shows the significant role of sports in our health. $25 \%$ of respondents fall ill out of those who are not engaged in sports activities.

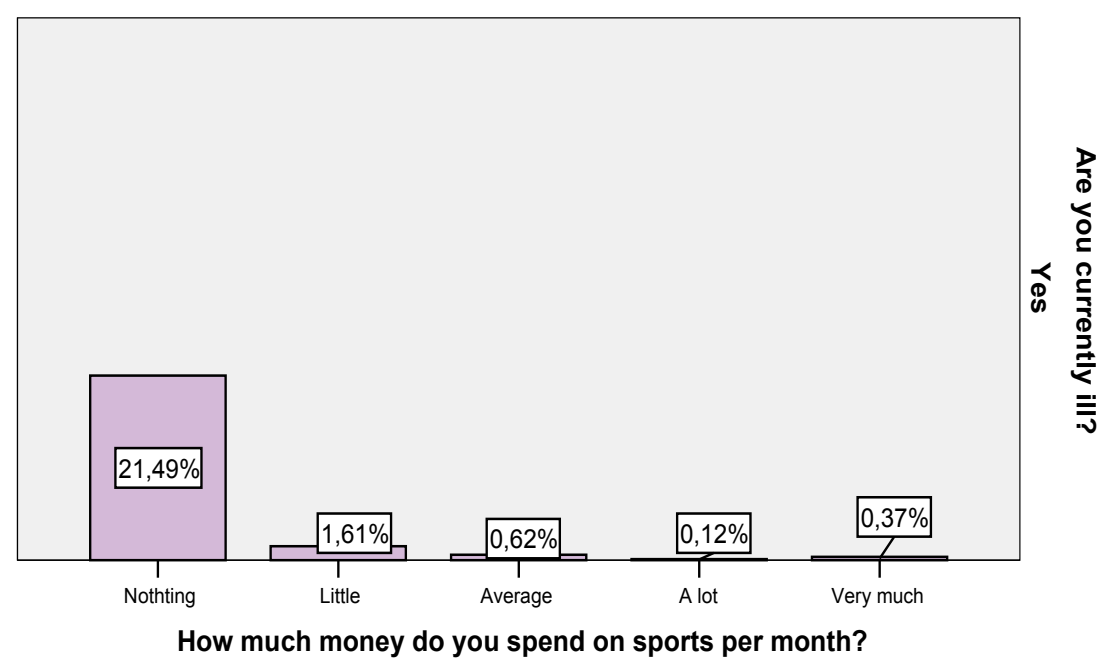

Figure 3. Relation of diseases and sports

Source: Authors' own research

Increasing posture problems, lack of exercise and obesity are due to general shifts in lifestyle: adults and children move less, sit much longer in front of the television, videos and computers. As regards dietary habits, the number of munchie eaters (consumption of sweets and refreshments) and fast food restaurant goers is surging.

Self-reporting on health and general condition (attitude towards life) is a widely used, excellent method for health state description. Relation between self report on state of health and willingness to do sports is demonstrated on Figure 4. Red columns show that those who do sports daily or weekly regard their state of health good or excellent. It indicates that physical exercise exerts positive influences on both physical and mental well-being. 


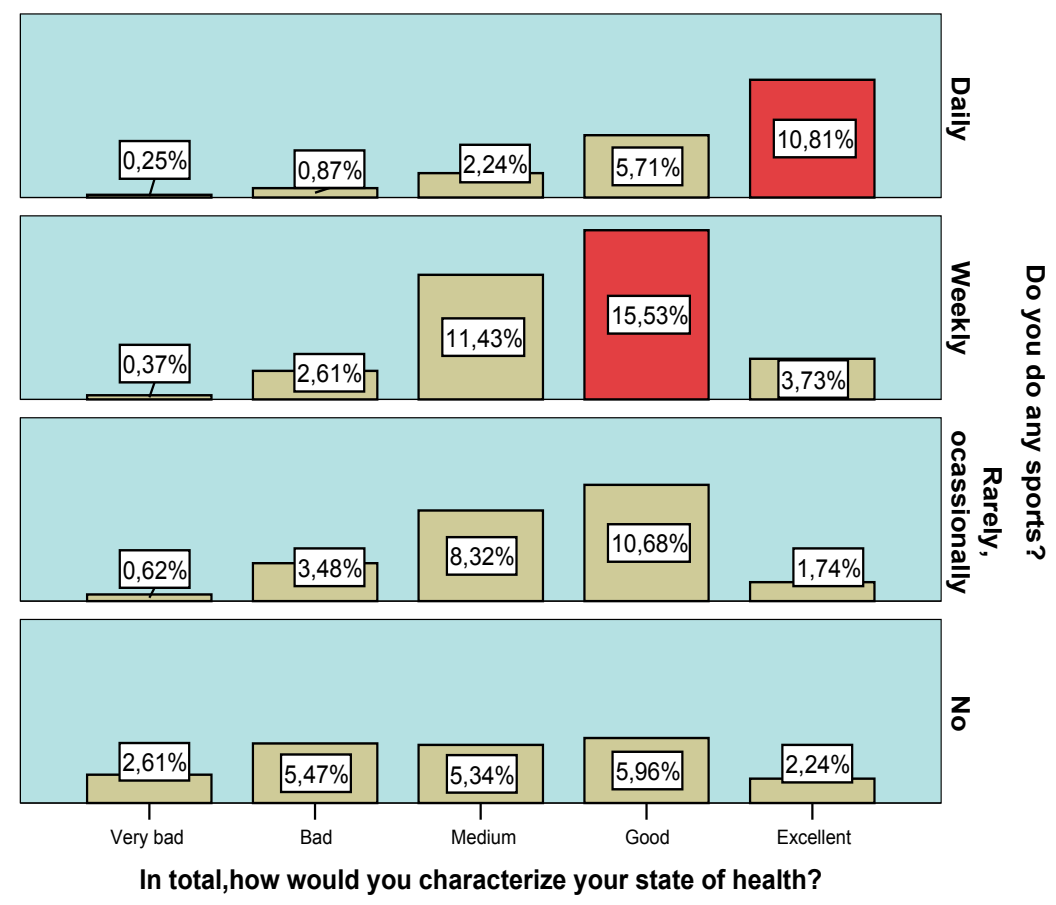

Figure 4. Relation of diseases and sports

Source: Authors' own research

Naturally, willingness to do sports is highly determined by monthly income (Table 3.) Some types of sporting activities do not require high investments (e.g. walking), but the truth is that long-term sporting and healthy life, even if they pay off, do have costs.

The same holds true for our health condition. This explains the fact that the higher the average per capita income, the better respondents find their health. $80 \%$ of those who earn above the average 100.000 HUF per month regarded their health good $(40 \%)$ or excellent $(40 \%)$.

Table 3. Relation of monthly average per capita income and health condition

\begin{tabular}{|c|c|c|c|c|}
\hline & & $\begin{array}{l}\text { How much is the } \\
\text { Below } 50000 \\
\text { HUF }\end{array}$ & \begin{tabular}{|l|} 
average per cap \\
$50-100000$ \\
HUF
\end{tabular} & $\begin{array}{l}\text { ita income in your household? } \\
\text { Above } 100000 \text { HUF }\end{array}$ \\
\hline $\begin{array}{l}\text { In total, how would } \\
\text { you characterize your } \\
\text { state of health? } \\
\text { Total }\end{array}$ & $\begin{array}{l}\text { Very bad } \\
\text { Bad } \\
\text { Medium } \\
\text { Good } \\
\text { Excellent }\end{array}$ & $\begin{array}{r}4,6 \\
16,9 \\
34,4 \\
26,7 \\
17,4 \\
100 \\
\end{array}$ & $\begin{array}{r}4,5 \\
12,9 \\
31,6 \\
42,1 \\
8,9 \\
100\end{array}$ & $\begin{array}{r}1,6 \\
6,8 \\
10,9 \\
40,1 \\
40,6 \\
100 \\
\end{array}$ \\
\hline
\end{tabular}

Source: Authors' own research

\section{Conclusions and recommendations}

To what extent we are healthy and how much we care about our health depend on several factors. Available data suggest that several subject matters should be investigated, such as the relation of body weight and height, frequency and types of health problems, visits to doctors, costs of medicines and sporting activities.

Lower than $50 \%$ of young people do sports. As years go by, willingness to do sports decreases. However, it is positive that one-third of people aged 45-60 do some kind of physical activity. 
Furthermore, it has been revealed that merely $50 \%$ of female respondents do exercises on a daily or weekly basis. This is not surprising, as much higher burdens are imposed on women than on men. They need to juggle household chores and child care and sport often falls in the background.

Survey findings have disclosed that those who do sports daily or weekly regard their state of health good or excellent. It indicates that physical exercise exerts positive influences on both physical and mental well-being.

Our findings also indicate that sports activities and physical exercises are in direct proportion to incomes and qualifications: higher incomes incite higher willingness to do sports. As mentioned earlier, those who pursue a higher rate of sports activities have stronger control over their lives, i.e. fitness and conscious health care are more essential for them.

Finally, in spite of these (sad statistical data) Hungarian population is more optimistic about their health as indicated by in-depth analysis.

\section{References}

Albrecht G. L., Devlieger P.J. 1999. The disability paradox: high quality of life against all odds. Social Science and Medicine. 1999. 48 (8): 977-988.

Arisztotelész 1997. Nikomakhoszi etika. Európa Kiadó. Budapest

Berger-Schmidtt N. 2000. Conceptual Framework and Structure of a European System of Social Indicators. $\mathrm{http} / / /$ www.social-science-tesis.de/en/social_monitoring/social_indicators/EU_reporting/pdf_files/paper9.pdf

Black D., Morris J. N., Smith C., Townsend, P. 1985. Inequalities in health. The Black Report. Penguin Books, Hammondsworth, Middlesex, England

Bosworth H.B., Schaie K.W. 1997. The relationship of Social Environment, Social Networks, and Health Outcomes in The Seattle Longitudinal Study: Two Analytical Approaches. Journal of Gerontology:

Psychological Sciences, 52B(5): 197-205

Cameron P., Titus, D.G. Kostin J., Kostin M. 1973. The life satisfaction of nonnormal persons. Journal of Consulting and Clinical Psychology, 41(2): 207-214.

Csíkszentmihályi M. 1998. És addig éltek, amíg meg nem haltak: a mindennapok minősége. Kulturtrade, Budapest. Idézi: Gábor Michalkó-Kornélia Kiss-Balázs Kovács-Judit Sulyok, 2009

Diener E., Biswas-Diener R. 2000. New Directions in Subjective Well-Being Reseasrch: The Cutting Edge. http://s.psych.uiuc.edu/ ediener/hottopic/paper1.html.

Diener E., Suh E., Oishi S. 1997. Recent Findings on Subjective Well-Being. http://s.psych.uiuc.edu/ ediener/hottopic/paper1.html.

Dobos J., Jeffres L. 1993. Perceptions of leisure opportunities and the quality of life in a metropolitan area. Journal of Leisure Research. 25. (2.) pp. 203-217.

Fekete Zs. 2006. Életminőség. Koncepciók, definíciók, kutatási irányok. - In: Utasi Á. (szerk.): A szubjektív életminőség forrásai: biztonság és kapcsolatok. - MTA Politikai Tudományok Intézete, Budapest, pp. 277-309.

Fisher M., Butt J., Moriarty J. 2000-2002. Quality of Life and Social Support Among Older People from Different Ethnic Group. Research Plan. Growing Older. The ESRC Research Programme on Extending Qualiity of Life.

Hankiss E., Manchin R., Füstös L. 1980. The role of values and value deficiencies in Primary Health Care Recording Systems. Budapest: Mủvelődéskutatási Intézet.

Hankiss, E. Manchin R. 1976. Szempontok az élet „minőségének” szociológiai vizsgálatához. Valóság, 1: 2034.

Hankiss E., Manchin R. 1977. Quality of Life Models: The Hungarian Experience. Indicators of Environmental Quality and Quality of Life, Paris: UNESCO.

Hankiss E., Manchin R., Füstös L., Szakolczai Á. 1981. Continuity and Discontinuity: Value Change in the US and in Hungary. Budapest. 
Hankiss E., Manchin R., Füstös L., Szakolczai Á. 1982. Kényszerpályán? A magyar társadalom értékrendszerének alakulása 1930 és 1980 között. 1-2. kötet. Budapest: MTA Szociológia Kutatóintézete, Értékszociológiai és Alkalmazott Társadalomtudományi Elemzések Műhelye.

Hegedűs R. 2001. Szubjektív társadalmi indikátorok - szelektív áttekintés a téma irodalmából. Szociológia Szemle, 2: 58-71.

Hegedűs R. 2002. Szubjektív társadalmi indikátorok - szelektív áttekintés a téma irodalmából. In Lengyel György (szerk.): Indikátorok és elemzések. Műhelytanulmányok a társadalmi jelzőszámok témaköréből. Budapest: BKÁE.

Inglehart R., Klingemann H-D. 2000. Genes, culture, democracy and happiness. In Diener, E.-Suh, E. (eds.): Subjective well-being across cultures. Cambridge, MA: MIT Press. http://wvs.isr.umich.edu/papers/genecult.pdf

Jurowski C., Brown D. 2001. A comparison of the views of involved versus noninvolved citizens on quality of life and tourism development issues. Journal of Hospitality \& Tourism Research. 25. (4.) pp. 355-370.

Kahneman D. 2002. A Day in the Lives of 1,000 Working Women in Texas. Paper presented at the First International Positive Psychology Summit. Gallup Building, Washington DC. October 3-6. 2002. http://www.gallup.hu/pps/kahneman.htm

Klinger A. 1987. A halandóság társadalmi foglalkozási különbségei Magyarországon. Demográfia 1987. 240272. 0 .

Kopp M., Pikó B. 2006. Az egészséggel kapcsolatos életminőség pszichológiai, szociológiai és kulturális dimenziói. - In Kopp M.-Kovács M. (szerk.): A magyar népesség életminősége az ezredfordulón. Semmelweis Kiadó, Budapest. pp. 10-19.

Kopp M., Skrabski Á., Szedmák S. 1999. A testi és a lelki egészség összefüggései országos reprezentatív felmérések alapján. Demográfia 1999/1-2. 88. o.

Kopp M., Skrabski Á. 2000. Pszichoszociális tényezők és egészségi állapot. Demográfia 2000/2-3. 252-277. o.

Lengyel Gy., Hegedüs R. 2002. A szubjektív jólét objektív tényezői nemzetközi összehasonlításban. In Lengyel György (szerk.): Indikátorok és elemzések. Mühelytanulmányok a társadalmi jelzőszámok témaköréből. Budapest: BKÁE.

Lengyel Gy., Janky Béla 2002. A szubjektív jólét társadalmi feltételei. In Lengyel György (szerk.): Indikátorok és elemzések. Mühelytanulmányok a társadalmi jelzőszámok témaköréből. Budapest: BKÁE.

Leon M., Gold D., Glass A., Kaplan L., George L. 2001. Disability as a Function of Social Networks and Support in Elderly African Americans and Whites: The Duke EPESE 1986-1992. J. Gerontol. B. Psychol. Sci. Soc. Sci., 56: S179-S190.

Losonczi Á. 1986. A kiszolgáltatottság anatómiája az egészségügyben. Magvető Kiadó, Budapest

Losonczi Á. 1989. Ártó-védő társadalom. Ahogy a társadalom betegít és gyógyít... Közgazdasági és Jogi Könyvkiadó, Budapest

Skrabszki, Á., Kopp, M. 1999. Társadalmi beállítottság, társadalmi tőke. Századvég, 12: 128-146

Utasi Á. 2002. A társadalmi integráció és szolidaritás alapjai: a bizalmas kapcsolatok. Századvég,. 2, http://www.szazadveg.hu/kiado/szv/archivum/24/utasi.html.

Utasi Á. 2000. A társadalmi szolidaritás és integráció. Fogalmi értelmezés, kategóriák és jelzőszámok. Budapest: $\mathrm{KSH}$.

Veenhoven R. 1997. The utility of happiness. http://www.eur.nl/fsw/personeel/soc/veenhoven/index2.htm 